\title{
Macroeconomic Impact of Refugee Inflow on West African Countries
}

\author{
Louis Sevitenyi Nkwatoh ${ }^{\mathrm{a},{ }^{*}} \&$ Kekere Sule Ibrahim ${ }^{\mathrm{b}}$ \\ ${ }^{a}$ Yobe State University, KM 7 Gujba Road, Damaturu and PMB 1144, Nigeria \\ ${ }^{b}$ Ahamadu Bello University, Samru Street, No 3, Nigeria
}

\begin{abstract}
This study investigated the macroeconomic effect of refugee inflow on West African Countries using the panel vector autoregressive approach over the period 1992 to 2018. Our results provide evidence that a positive refugee shock induces a positive effect on GDP per capita, government consumption and labour force. On the other hand, the effect of a shock to refugee exerts a negative effect on the fiscal balance of host Countries. The overall result from the variance decomposition indicates that refugees prefer to migrate to Countries with better economic activities as reflected by the GDP per capita and labour supply, even though the magnitude of contribution of refugees to economic activities is small and significant only in the short run. Hence, refugees do not constitute an economic burden to West African States, but however, induce a negative effect on their fiscal balance via extra budgetary expenditure. This calls for a global response to refugee crisis with respect to its fiscal implication on host Countries. This may go a long way in averting another circle of crisis because refugees often exacerbate the worsening economic and social problems of host Countries, leading to increase in government consumption.
\end{abstract}

Keywords: Refugees; Macro-economy effect; Panel VAR; West Africa.

\section{Introduction}

The number of refugees/migrants in recent time has taken an unprecedented dimension globally. This trend is mostly driven by socio-economic, political and ecological forces. In addition to these drivers, the rising trends of conflicts and insecurity, particularly in some African Countries have resulted to a large population movement, or flow of refugees to neighbouring Countries. The vast majority of the World's refugees reside in developing Countries with Turkey, Pakistan and Lebanon hosting 30\% of the world's refugees (UNHCR, 2017), while $28 \%$ live in low-income Countries, such as Cameroon, Chad, the Democratic Republic of the Congo, Ethiopia, Kenya, Sudan and Uganda (OECD, 2017).

The current refugee crisis is a catastrophe that is affecting most economies since it always redirects government spending as well as thwart policy objectives of host countries. In their submission, Hennessey and Hagen-Zanker (2020) note that migrants often drain public finances or take advantage of the national welfare systems. Implicitly, refugees endanger the stability of host countries because they often increase the share of migrants in the labour force and place undue burdens on the public purse. This underscores the fact that the entire macroeconomic structure of host economies can be distorted by massive inflows of refugees. According to World Bank (2012) and UNHCR (2004) reports, the negative effect of refugee inflows on host countries often translates into increasing prices and demand for food, housing, education, transportation, health provisions, infrastructure as well as competition with host communities for natural resources such as grazing and firewood.

The Economic Community of West African States (ECOWAS), through various protocols has established a number of agreements that seek to promote cooperation and strengthen regional integration. To this end, a regional legal framework that establishes freedom of movement by nationals of member countries is articulated in the various

\footnotetext{
* Corresponding author.

E-mail address: sevinkwatoh@gmail.com (Louis Sevitenyi Nkwatoh)
} 
agreements and Treaties (see Elumelu, 2014). Sequel to this legal framework, a Migration and Development Action Plan, which lays emphasis on the protection of the rights of migrants, asylum seekers and refugees has been adopted by all members (see, UNHCR, 2007).

Even with this legal framework, the overall public finances have deteriorated in recent years and threatening to undermine the macroeconomic management of the region (see ECOWAS Annual Report, 2016). Implicitly, the rising inflow of refugees into and among ECOWAS countries due to the many political conflicts, insecurity and natural disasters may further weaken their general macroeconomic performance. For instance, in 2009, the total number of refugees in the ECOWAS region, excluding Cape Verde had risen to 149,026. The number rose to 300,616 and to 326,287 in 2016 and 2018 respectively (UNHCR, 2019). During the same period, the region's average deficit-toGDP ratio deteriorated from 3.2\% to 3.5\% to 45\% and slightly improved to 3.7\% in 2009, 2012, 2014, 2016 and 2018 respectively (IMF-WEO's country data, 2019). Only Gambia, Benin and Côte D'Ivoire recorded a low average deficit-to-GDP ratio of approximately 1.9\%, 2.1\% and 2.7 between 2009 and 2018, with Ghana, Serie Leone and Niger recorded a high average deficit-to-GDP ratio of approximately 5.9, 4.6 and 4.2 respectively. The overall fiscal balance in ECOWAS is deteriorating implying that increasing inflow of refugees will further exert pressure on the fiscal balance of host countries. Therefore, it is imperative to analyze the macroeconomic impact of refugee inflow on West African Countries.

The balance of the paper is organized as follows: Section 2 presents a review of related studies. Section 3 ushers in the methodology. Section 4 reports and discusses the results, while Section 5 highlights the policy implication and recommendations.

\section{Theoretical Framework/Literature Review}

\subsection{Theoretical Framework}

Before discussing the theoretical foundation of refugee, it is important to understand what constitute the typologies put forward to describe migrants. The basic form identified in the literature is underpinned by motivation for and causes of migration and those concerned with location and times. On the basis of both voluntary and involuntary migration, Peterson (1958) defined a typology of migrants in terms of relation (migratory force) these includes; nature and man (ecological push); state and man (migration policy). The first category of migrants is driven by primitive (conservative) migration, when people move to preserve or retain their way of life. The second category includes impelled or forced migrants. This second category lies at the heart of the global refugee crisis where people in large numbers seek refuge in foreign land due to one problem or the other in their country. In West Africa, for instance, the refugee problems are driven by conflict that is either political or driven by religious extremism.

The structuralist models or theories consider migration as a passive response to the socio-economic and political environment beyond the control of the individuals migrating. In other words, individuals respond to the social structure in which the find themselves. Richmond (1988) draws from the structuralist perspective to suggest that the extent of freedom of all migrants is constrained by the social structure in which they exist. According to him, they are classified based on the degree to which they can exercise autonomy. The degree of this autonomy can be proactive or reactive. Richmond describe those that exercise greater autonomy as proactive, while those that exercise more constraint to be reactive.

The second category of migration theory is the scientific and system model. According to Malogunje (1970) a system is described as a complex of interacting elements, together with their attributes and relationships operates within an environment that affect and is affected by the system. According to him, this neatly describes the pattern of ruralurban migration, with their key drivers being the potential migrants, rural and urban institutions. Another variant of the system model by Hoffman-Nowotny (1981) considers migration as one process within a larger system. According to this approach, migration is a by-product of tension within a system that emanated as a result of the interplay between power and prestige. In this context, migration outside a system becomes a likely outcome when there is an imbalance between power and prestige. This happens if response within the system is unable to resolve the imbalance or does not provide a solution. Formal network analysis by Nogle (1994) to identify key determinants of migration pattern in the European Union provides a much recent application of the system approach. His study highlights the 
significance of common languages, relative distance and trade as the major drivers of migration. The present study is anchored on the work of Nogle (1994) system model by investigating the macroeconomic effect of refugee crisis in West African countries.

Most West African countries have experienced an upsurge of refugees from neighboring countries that are experiencing various degrees of conflict. These crises are mostly the result of socioeconomic, political and religious factors, as well as climate change related issues that have caused food shortages in most of these countries, forcing migration to other countries. These had led to negative impact on the host countries' economy. For instance, Fig. 1 shows that the inflows of refugees to host countries have led to rise in consumer prices due to upsurge in demand for food, competition for available jobs, causing negative labor market outcomes and sometimes, conflict with communities due to competition for available amenities.

\subsection{Literature Review}

Earlier literature on the macroeconomic impact of refugee flows on host communities like Alix-Garcia, Bartlett, and Saah (2012) use data on a displaced population to analyze movements from rural to urban areas in Sudan, their result showed that food aid impacts local prices, food, housing and labor markets. Similarly, empirical studies on the link between refugee inflows and the hospitality industry of host countries find negative impact of refugee crises on the hotel industry (see Ivanov et al., 2016; Ivanov, Gavrilina, et al., 2017; Ivanov, Sypchenko, et al., 2017; Ivanov \& Stavrinoudis, 2018). Also, Zenker et al (2019) examined the impact of refugee crisis on the decision structure of tourist for four different countries (Austria, Germany, UK and USA). Their results show that the perceived security of a place becomes a stronger predictor for destination choice during a crisis. Yet, contrary to earlier held assumption, a crisis decreases the importance of a place's perceived openness. Thus, the study raises doubts that the refugee crisis benefits tourism by providing an opportunity to show openness and hospitality.

Similarly, Saiz and Wachter, (2011), Accetturo et al. (2014), Sá (2015), Lastrapes and Lebesmuehlbacher (2016), Tumen (2016), Balkan et al (2018), Vuuren et al (2019) found evidence on the relationship between refugee inflows and demand for housing facilities in host countries' economy. For instance, Tumen (2016) found evidence on the impact of Syrian refugees on consumer prices, labor market outcomes, and housing rents in Turkey. A similar conclusion was also reached by Balkan et al (2018) who found that refugee inflows have led to an increase in the rents of housing units. Using difference-in-difference approach Vuuren et al (2019) find support for a negative and significant price effect of around 4 percent for apartments that were within a 5-minutes walking distance from the building sites, while there is no impact for houses situated at long distances. Although Sá (2015) concludes that increase in the stock of immigrants result in a decrease in house prices, her result is explained by an outflow of the highest earning families due to negative impact in the poorest neighborhoods.

Other studies like, Chambers (1986), Jacobsen (2002), Baloch et al (2017) and Betts et al. (2014) approach refugee impact through the lens of a protracted refugee situation, for instance, Baloch et al (2017) examine the impact of refugee crisis on neighboring host country utilizing data for the period 1979-2014 and the ARDL bounds testing approach. The empirical results indicate that Afghan refugees have a strong negative impact on economic growth in Pakistan. The effect holds in both the short run and the long run, suggesting that the influx of refugees lowers real economic activity in the country. Chambers (1986) viewed the impact of refugee on host country from its impact on people of different categories rather than the government. Viewed from the perspective of a poor host country, the poorer hosts can lose from competition for food, work, wages, services, and common property resources. According to World Bank, (2012), UNHCR, (2004) competition with host communities for natural resources such as grazing and firewood can also arise due to refugee influx. Also, Friedberg and Hunt (1995) posits that low-skilled refugees will significantly expand the supply of labour for un-skilled occupations, lower the wage level and increase unemployment in host communities. According to Rother et al., (2016) migration of refugee will naturally lead to the process of urbanization and shift to the population demography in host countries.

Although a large body of literature has shown that refugees can be of economic benefit, amongst them include; UNHCR (2011), Milner (2016), Lagrain (2017), Fallah et al. (2019). According to UNHCR (2011), refugees can have positive economic impacts by creating job openings, or by contributing to agricultural production of the local economy. Similarly, in the words of Milner (2016) refugees can have positive impacts on the receiving countries' 
economy by attracting development partners to work with the local community alongside aid workers, also, refugees who are allowed to work can contribute to agricultural production and the local economy. Fallah et al. (2019) used individual level panel data from Jordan before and after the Syrian refugee influx to examine the impact of a refugee influx on natives' labor market outcomes using a variety of difference-in-difference models. They found that Jordanians living in areas with high concentrations of refugees had no worse labor market outcomes than Jordanians with less exposure to the refugee influx.

There is another strand of research indicating that refugees have the tendency to destabilize host countries. This may be in the form of political activists seeking to use recipient country as a launch-pad for mobilizing and recruiting insurgents (Zolberg, Suhrke and Aguayo 1989) or possibly even harbor fighters masquerading as refugees (Lischer 2005; Salehyan and Gleditsch 2006). Although some studies show mixed results, for instance, Dzimbiri (1993) showed that there was a significant strain on administration structures and health facilities, but many new jobs were created.

Due to the rising trend in refugee crises across Africa and Middle East, a market-based solution in the context of refugee resettlement was proposed by researchers in the field of international law. The work by Schuck (1997) and, Hathaway and Neve (1997) pioneered the discussion of bilateral negotiations over tradable refugee resettlement. In the system proposed by Hathaway and Neve (1997), poorer states would agree to host refugees, while richer states would agree to finance the costs of refugee incurred by the host country. For instance, Azernat (2018) studies the effect of refugee resettlement on human capital accumulation using a growth model with endogenous fertility. He showed that refugee resettlement from a more advanced and wealthier economy to a less advanced and less wealthy economy combined with income transfers is Pareto-improving for indigenous populations in both countries. Related literature on the macroeconomic impact of refugee on host country abounds in Africa, especially, as these countries have been plunged into different conflict in the last few decades. Earlier literature in this regard includes the work of Alix-Garcia and Saah (2010) that examine the impact of refugees from Rwanda and Burundi on food prices in Tanzania, while Taylor et al. (2016) look at the impact of refugees from the Congo on income in Rwanda. Alloush et al (2017) examined economic life in three Congolese refugee camps in Rwanda and the interactions between refugees and local host-country economies within a $10-\mathrm{km}$ radius around each camp and find that despite undergoing forced migration and often living in destitute conditions, refugees actively interact with host country economies. This result in a divergence of refugee household income from the assistance they receive, and strengthened market linkages between camp and host economies. The present study departs from the existing work by looking at the macroeconomic impact of refugee influx on the economy of 14 West African countries (receiving countries).

\section{Methodology}

\subsection{Data}

The study used annual secondary data from 1992 to 2018 to accommodate recent trends in refugee inflow into West African Countries. Data for 14 West Africa Countries were considered, with the exclusion of Cape Verde due to paucity of data. The main variables used in the analysis are Refugee inflow, Labor Force, GDP per capita, Government Consumption and Fiscal Balance. Data for Refugee inflow was extracted from United Nation High Commissioner web site; Labour Force was taken from International Labour Organisation web site, GDP per capita, Fiscal Balance and Government Consumption were extracted from IFS Statistic and World Bank Development Index websites. All the variables were logged except for fiscal balance because of its negative values.

\subsection{Model Specification}

This study used a panel VAR (PVAR) model adopted from Love \& Zicchino's (2006) study. The model simulates the traditional VAR models, which all the variables in the system are endogenous, and a panel-data approach, which allows for unobserved individual heterogeneity. The adopt VAR specification is as follows:

$$
Y_{i t}=\Gamma(L) Y_{i t}+U_{i t}+\varepsilon_{i t}+f i
$$

Where, $Y_{\text {it }}$ is a vector of stationary variables, $\Gamma(L)$ is a polynomial matrix with a lag operator, $U_{\text {it }}$ is a vector of country specific effects and $\varepsilon_{i t}$ is a vector of idiosyncratic errors of refugee inflow to the other variables. $f i$ is the 
fixed effect, which allows for individual heterogeneity across the countries. $Y_{i t}$ is a five variables vector: (Refugee inflow, GDPPC, Laborforce, GovConsumption, Fisacal_balance). The estimation followed the Cholesky ordering, while the LR, FPE AIC SC and HQ as well the LM tests were used respectively to determine the VAR lag length consistent with the absence of serial correlation. The impulse response graphs and variance decompositions were derived from PVAR estimates using the Cholesky decomposition.

\section{Empirical Results}

This section presents the impulse response functions (IRF) and the variance decomposition from the PVAR model. The IRFs were generated using the Monte Carlo simulations with 300 repetitions. The IRFs lie between the upper and lower dotted lines which constitute $95 \%$ confidence interval over the next 12 years horizon. The five-variable-PVAR model consists of Refugee, GDP per capita (GDPPC), GovConsumption as a percentage of GDP, Fiscal Balance as a percentage of GDP and Labour force as a percentage of the population.

Before implementing the PVAR model, the variables were screened in order to ascertain the order of integration (stationarity) and to overcome spurious regression by employing a panel unit root tests with intercept and trend. Table 1 reports the summary results of unit root tests of IPS, ADF, and PP for the variables at $5 \%$ level of significance. The results indicate that GDP per capita, and Government Consumption are stationary at first difference, while Refugee inflow and Labour Force are stationary at second difference, and Fiscal Balance is stationary at level.

Table 1. Panel Unit Root Test

\begin{tabular}{|c|c|c|c|c|c|c|c|c|c|c|}
\hline & \multicolumn{4}{|c|}{ Im, Pesaran and Shin } & \multicolumn{2}{|c|}{ ADF-Fisher } & \multicolumn{3}{|c|}{ PP-Fisher } & \multirow[b]{2}{*}{$\begin{array}{c}\text { Integration } \\
\text { Order }\end{array}$} \\
\hline & Level & $1^{\text {st }}$ Diff & $2^{\text {nd }}$ Diff & Level & $1^{\text {st }}$ Diff & $2^{\text {nd }}$ Diff & Level & $1^{\text {st }}$ Diff & $2^{\text {nd }}$ Diff & \\
\hline Refugee & $\begin{array}{l}-0.931 \\
(0.17)\end{array}$ & $\begin{array}{c}0.14 \\
(0.55)\end{array}$ & $\begin{array}{c}-5.6 * * \\
(0.00)\end{array}$ & $\begin{array}{c}39.2 \\
(0.72)\end{array}$ & $\begin{array}{l}24.16 \\
(0.67)\end{array}$ & $\begin{array}{l}90.34 * * \\
(0.002)\end{array}$ & $\begin{array}{c}29.5 \\
(0.38)\end{array}$ & $\begin{array}{c}36.6 \\
(0.18)\end{array}$ & $\begin{array}{c}187.2 * * \\
(0.00)\end{array}$ & $\mathrm{I}(2)$ \\
\hline GDPPC & $\begin{array}{c}1.9 \\
(0.77)\end{array}$ & $\begin{array}{c}-5.4 * * \\
(0.00)\end{array}$ & & $\begin{array}{c}15.6 \\
(0.99)\end{array}$ & $\begin{array}{c}79.33^{* * *} \\
(0.00)\end{array}$ & & $\begin{array}{l}16.29 \\
(0.96)\end{array}$ & $\begin{array}{c}181.3^{* * *} \\
(0.00)\end{array}$ & & $\mathrm{I}(1)$ \\
\hline $\begin{array}{l}\text { Labor } \\
\text { Force }\end{array}$ & $\begin{array}{l}-0.73 \\
(0.23)\end{array}$ & $\begin{array}{c}0.97 \\
(0.84)\end{array}$ & $\begin{array}{l}-6.2 * * \\
(0.00)\end{array}$ & $\begin{array}{l}46.9 * * \\
(0.01)\end{array}$ & $\begin{array}{c}20.3 \\
(0.85)\end{array}$ & $\begin{array}{l}89.5 * * \\
(0.00)\end{array}$ & $\begin{array}{l}21.56 \\
(0.8)\end{array}$ & $\begin{array}{c}19.0 \\
(0.89)\end{array}$ & $\begin{array}{c}434.0 * * \\
(0.00)\end{array}$ & $\mathrm{I}(2)$ \\
\hline $\begin{array}{l}\text { Government } \\
\text { Consumption }\end{array}$ & $\begin{array}{c}0.99 \\
(0.84)\end{array}$ & $\begin{array}{c}-7.4 * * \\
(0.00)\end{array}$ & & $\begin{array}{c}21.4 \\
(0.81)\end{array}$ & $\begin{array}{c}110.1 * * \\
(0.00)\end{array}$ & & $\begin{array}{l}21.8 \\
(0.79)\end{array}$ & $\begin{array}{l}201.3 \\
(0.00)\end{array}$ & & $\mathrm{I}(1)$ \\
\hline Fiscal Balance & $\begin{array}{l}-2.7 * * \\
(0.03)\end{array}$ & & & $\begin{array}{l}50.1 * * \\
(0.006)\end{array}$ & & & $\begin{array}{l}94.3 * * \\
(0.001)\end{array}$ & & & $\mathrm{I}(0)$ \\
\hline
\end{tabular}

NB: (*) Represent the probability Values. The null hypothesis for all test is a unit.

Source: Author's computation using Eviews 9 (2015)

\subsection{Diagnostic Tests}

Table 2 shows the optimal lag lengths and serial correlation LM tests for the different PVAR models. The optimal lag lengths were chosen in order to ensure that the estimation of the VAR model is consistent and free from serial correlation. Lag 5 was chosen based on the Akaike Information Criterion (AIC) and Sequential modified LR statistic, and also because of the absence of serial correlation at $5 \%$ level of significance (in Table 2).

\subsection{Stability Test}

The next important test that follows the serial correlation LM-test is the VAR stability test. The estimated VAR model is stable (stationary) if all roots have modulus less than one and lie inside the unit circle (Agung, 2009). Thus, the estimated VAR model for West Africa fulfils the stability condition. All initial preliminary VAR diagnostics have been fulfilled. 
Table 2. Lag Length Criteria and LM-Serial Correlation Test

\begin{tabular}{rllllll|rc}
\hline Lag & LogL & LR & FPE & AIC & SC & HQ & LM-Stat & Prob \\
\hline 0 & 1203.144 & NA & $8.42 \mathrm{E}-11$ & -9.0086 & -8.94125 & -8.98154 & 36.0737 & 0.0705 \\
1 & 1419.839 & 423.6138 & $1.99 \mathrm{E}-11$ & -10.4499 & $-10.04576^{*}$ & $-10.2875^{*}$ & 55.19207 & 0.0005 \\
2 & 1460.032 & 77.06095 & $1.78 \mathrm{E}-11$ & -10.5642 & -9.8232 & -10.2665 & 36.11463 & 0.0699 \\
3 & 1498.206 & 71.75609 & $1.61 \mathrm{E}-11$ & -10.6632 & -9.58546 & -10.2302 & 37.21711 & 0.0551 \\
4 & 1526.438 & 52.00613 & $1.57 \mathrm{E}-11$ & -10.6875 & -9.27296 & -10.1192 & 43.89524 & 0.0111 \\
5 & 1559.638 & $59.91092^{*}$ & $1.48 \mathrm{e}-11^{*}$ & $-10.74916^{*}$ & -8.99783 & -10.0456 & 24.58959 & 0.4856 \\
6 & 1580.014 & 36.00273 & $1.54 \mathrm{E}-11$ & -10.7144 & -8.62627 & -9.87551 & 24.58959 & 0.4856 \\
\hline
\end{tabular}

Source: Author's computation using Eviews 9 (2015).

Inverse Roots of AR Characteristic Polynomial

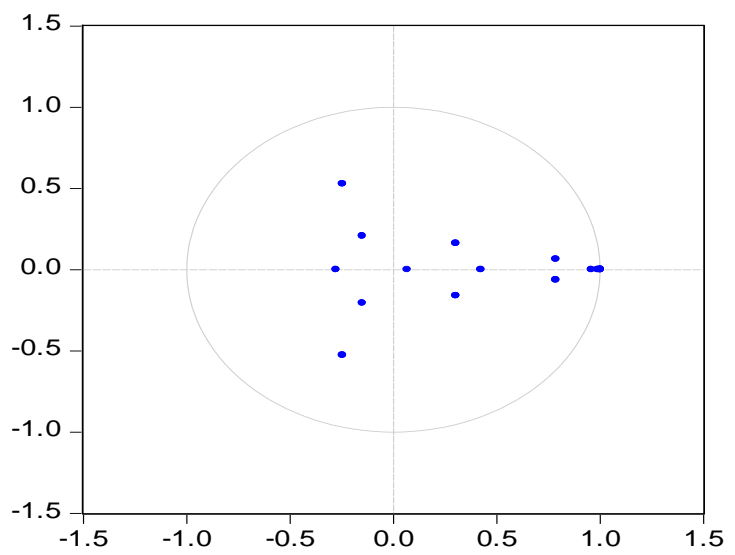

Fig. 1. AR Graph for Stability

Source: Author's plots using Eviews 9 (2015).

\subsection{Impulse Response Function}

Figure 1 shows the response of the GDP per capita, labour force, government consumption, and fiscal balance to a 1 standard deviation shock to refugee inflow. Panel one shows that GDP per capita responds positively to an exogenous shock to refugee inflow reaching its peak in the $7^{\text {th }}$ quarter of approximately $0.58 \%$. Thereafter, it declines very slightly, while remaining positive till the end of the $12^{\text {th }}$ quarter. This result indicates that the economic impact of refugees may be positive in West African countries. This result in line with some previous studies such as Boubtane Coulibaly \& Rault (2013) who concluded that asylum seekers are not a "burden" to Western European countries, but rather, makes the GDP per capita to increase positively. Weber \& Weigand (2016) also confirmed that GDP per capita responds positively to refugees in the short run for the case of Germany.

Panel two, shows that labour force responds positively to an exogenous shock to refugees, with a steady increase, reaching its peak in the $5^{\text {th }}$ quarter of approximately $0.2 \%$, and declines very slowly till the end of the last quarter. The implication here is that participation in the labour force increases in the short run with the inflow of refugees into West African countries. A plausible explanation is that a portion of the refuges is qualified to integrate into the job market, while others have acquired entrepreneurial skills that warrant them to start off a business. The slight decline in the long run may be due to the fact that the qualified refugees will either return to their Countries of origin or most of them will leave for greener pastures abroad (specifically Europe, America and Canada). 
Panel three indicates that government expenditure responds positively to an exogenous shock to refugee reaching its peak in the $6^{\text {th }}$ quarter of approximately $1.69 \%$ and declines steadily and positively in the long run reaching its minimum value of approximately $27 \%$. This implies that West African States will increase their spending habit during the inflow of refugees in line with international laws and Treaties. Again, their expenditures decline with a reduction in refugee inflow in the long run, as established by a decrease in labour participation. Yogo (2017) found that refugee shock induces an increase in government spending in the very short run for the case of Europe, in line with the current finding of this study.

Lastly, Panel four shows that fiscal balance responds negatively to an exogenous shock to refugee both in the long and short runs. Basically, this result is expected because respective governments in West Africa often experience social and economic burden, and fiscal pressure due to refuge inflow since their activities is financed via extra budgetary expenditure. This implies that the inflow of refugees exerts fiscal pressure on host Countries in West Africa. Better put, refugee inflow and fiscal balance are negatively correlated both in the long and short runs.

Accumulated Response to Cholesky One S.D. Innovations \pm 2 S.E.

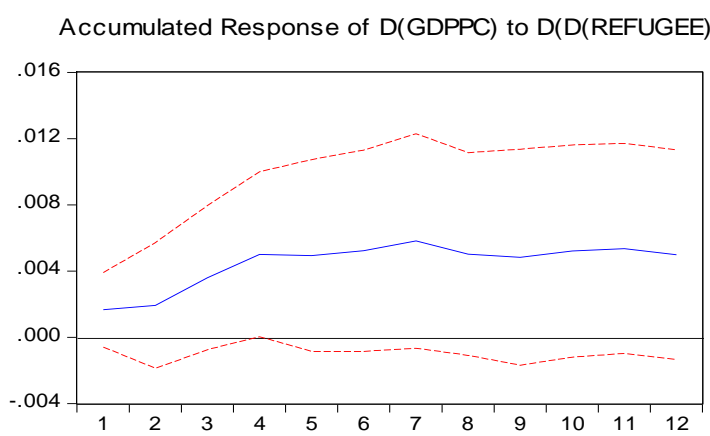

Accumulated Response of $D(D(L A B O U R F O R C E))$ to $D(D$ (REFUGEE))

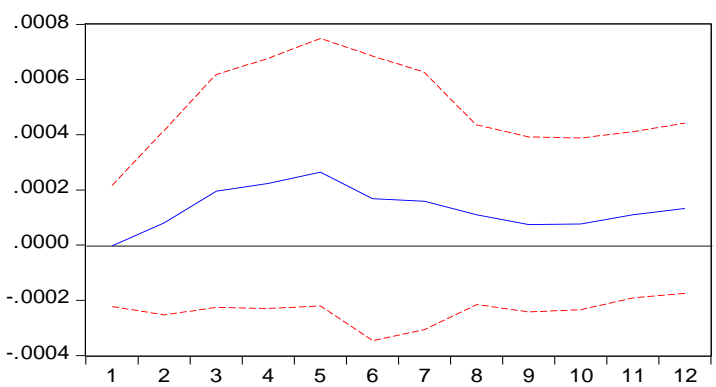

Accumulated Response of D(GOVCONSUMPTION) to D(D(REFUGEE))

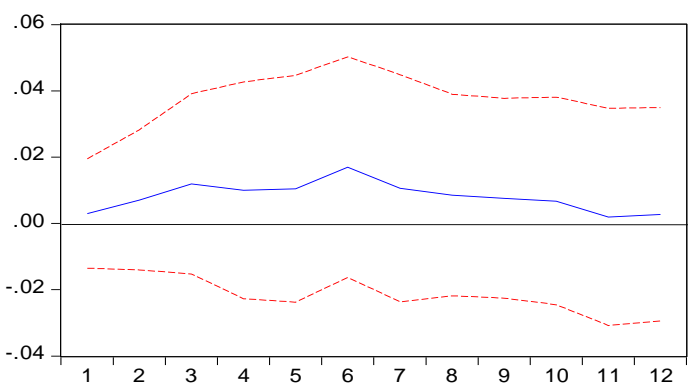

Accumulated Response of FISCAL_BALANCE to D(D(REFUGEE))

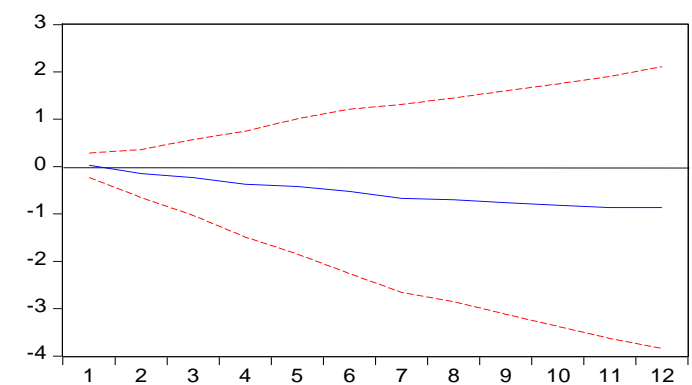

Fig. 2. Impulse Response Graph to Changes Refugees

Source: Author's plots using Eviews 9 (2015).

\subsection{Variance Decomposition}

The impulse response functions provide information about the effect of changes in one variable on another, but don't show the relative importance of the influence of shocks on the fluctuations of other variables. Alternatively, the variance decomposition is used to evaluate the order of importance of the fluctuations in one variable to other variables.

Table 2 presents the variance decomposition analysis in $\%$, for twelve periods ahead. The results indicate that GDP per capita and labour force on an average, explain approximately $1.26 \%$ and $1.02 \%$ respectively of the variations of refugee inflow, while government consumption and fiscal balance contribute $0.94 \%$ and $0.23 \%$ of the fluctuations of 
refugee inflow in the host Countries. The results also indicate that the variations of GDP per capita and fiscal balance are highly explained by labour force, which approximate 3.33\% and $0.68 \%$ respectively. Lastly, only GDP capita highly accounts for the fluctuations in government consumption with an approximate value of $6.43 \%$.

In summary, the findings suggest that many refugees key into the economic activities of host countries, most especially as they supply additional labour, which increases their productive capacity. The results further suggest that, refugees prefer to migrate to countries with better economic activities as reflected by GDP per capita (see, Boubtane, Coulibaly \& Rault, 2012). Hence, refugee inflow is positively associated with better economic activities and job opportunities. Remarkably, West African countries are expanding in terms of growth, economic activities and high demand for labour. This suggests that a portion of the total labour supply can be contributed by both natives of host countries and another portion by refugees. Apparently, labour supply (supplied by the native population plus a portion of the refugees) drives economic activities upward in West Africa. The finding is shored up by the results reported on Table 5, which indicates that labour supply highly accounts for the variations of the variables positively. However, the overall magnitude of contribution of the variables to refugees is small and significant only in the short run, possibly because host countries' efforts to properly integrate them in their economic process is little. Conclusively, there is co-movement between refugee inflow and economic activities, which exerts a negative effect on the fiscal structure of West African countries.

Table 3. Variance Decomposition Analysis in \%, for Twelve Periods Ahead

\begin{tabular}{cccccc}
\hline \multicolumn{5}{c}{ Variation in the Row Variable Explained by Column Variable } \\
\hline & $\mathrm{d}(\mathrm{d}($ Refugee $)$ & $\mathrm{d}($ GDPPC $)$ & $\mathrm{d}(\mathrm{d}($ LabourForce $))$ & $\mathrm{d}$ (GovConsumption) & Fiscal_Balance \\
\hline $\mathrm{d}(\mathrm{d}($ Refugee $)$ & 96.56 & 1.26 & 1.02 & 0.94 & 0.23 \\
$\mathrm{~d}($ GDPPC $)$ & 1.23 & 94.3 & 3.32 & 1.06 & 0.1 \\
$\mathrm{~d}(\mathrm{~d}$ (LabourForce $))$ & 0.4 & 8.45 & 89.84 & 0.67 & 0.64 \\
$\mathrm{~d}($ GovConsumption $)$ & 0.4 & 6.43 & 0.96 & 91.2 & 1.01 \\
Fiscal_Balance & 0.38 & 1.09 & 0.68 & 0.45 & 97.4 \\
\hline
\end{tabular}

Source: Authors' calculation using Eviews 9 (2015).

\section{Conclusion}

This study investigated the macroeconomic effect of refugee inflow in West African countries using a panel vector autoregressive approach over the period 1992 to 2018. Our results provide evidence that a positive refugee shock induces a positive effect on GDP per capita, government consumption and labour force. On the other hand, the effect of a shock to refugee exerts a negative effect on the fiscal balance of host countries. The overall result from the variance decomposition indicates that refugees prefer to migrate to countries with better economic activities as reflected by the GDP per capita and labour supply, even though the magnitude of contribution of refugees to economic activities in host countries is small and significant only in the short run. We therefore conclude that refugees do not constitute an economic burden to West African States, but however, induce a negative effect on their fiscal balance.

The policy implication here is that, even though West African countries can derive some economic benefits from refugee inflow, their rising numbers will, however reduce the fiscal balance specifically via extra budgetary expenditure, and distort the initial fiscal objectives of host countries, thereby forcing them to expand their revenue base. This calls for a global response to refugee crisis with respect to its fiscal implication. This may avert another circle of crisis because refugees often exacerbate the worsening economic and social problems of host countries, leading to increase in government consumption.

A major recommendation is that governments of respective West African countries should expand their revenue base. This will increase the fiscal balance profile, thereby easing the financing of activities of refugees via extra budgetary expenditure. Also, they need to amend their immigration policies in line with international Treaties that seek to 
integrate more refugees into the labour market both in the short and long runs, since they are a potential source of labour supply. This will contribute significantly to the growth process of the respective host countries, further expand their economic activities and also contribute to the nations' purse through tax collection (from refugees). However, thorough scrutiny is imperative because most refugees often migrate with fake credentials and false representation.

\section{References}

Accetturo, A., Manaresi, F., Mocetti, S., \& Olivieri, E. (2014). Don't stand so close to me: the urban impact of immigration. Reg. Sci. Urban Econ. 45, 45-56.

Agung, N. (2009). Time Series Data Analysis Using EViews. Statistical Papers, 52 (2), 497-499.

Alloush, M., Taylor, E., Gupta, A., Valdes, R., \& Gonzalez-Estrada, E. (2017). Economic life in refugee camps. World Development, 95, 334-347.

Azarnert, L.V. (2018). Refugee resettlement, redistribution and growth. European Journal of Political Economy, $54(C), 89-98$.

Balkan, B., Ozcan T, Torun, H., \& Tumen, S., (2018). Immigration, Housing Rents, and Residential Segregation: Evidence from Syrian Refugees in Turkey. Working paper. Stockholm School of Economics.

Baloch, A., Shah, S. Z., Noor, Z. M., \& Lacheheb, M. (2017). The Economic Effect of Refugee Crises on Neighbouring Host Countries: Empirical Evidence from Pakistan. International Migration, 55(6), 90-106.

Burns, K. (2008). Xenophobia-evolved 'outgroup' hatred or product of a toxic social environment? In: Mujawamariya, C (2013). Living with Xenophobia: Understanding the lived experiences of Burundian and Rwandese refugees in Durban (South Africa), being a thesis submitted for the award of Masters in Social Work, University of Kwazullu Natal.

Chambers, R. (1986). Hidden Losers? The impact of rural refugees and refugee programs on poorer hosts. International Migration Review, 20(2), 245-63.

Dadush, U., \& Neibuhr, M. (2016). The economic impact of forced migration, OCP Policy Centre, RP-16/03.

Dassah, M. (2015). Naming and exploring the causes of collective violence against African migrants in post-apartheid South Africa: Whither Ubuntu1? The Journal for Transdisciplinary Research in Southern Africa, 11(4), 127142.

Dzimbiri, L. B. (1993). Political and Economic Impacts of Refugees: Some Observations on Mozambican Refugees in Malawi. Refugee, 13(6), 4-6.

Ejoke, U.P., \& Ani, K.J. (2017). Historical and theoretical analysis of xenophobia in South Africa. Journal of Gender, Information and Development in Africa, 6(1-2), 163-185.

European Commission (2014). Coverage and Structure of the Labour Market Reform (LABREF) Database, Directorate General Economic and Financial Affairs, European Commission, November 2014.

EViews 9. (2015). User's Guide II Copyright c $1994\{2015$ IHS Global Inc. http://schwert.ssb.rochester.edu/a425/EV92.pdf.

Fallah, B., Krafft, C., \& Wahba, J (2019). The impact of refugees on employment and wages in Jordan. Journal of Development Economics, 139, 203-216

Friedberg, R.M., \& Hunt, J. (1995). The Impact of Immigrants on Host Country Wages, Employment and Growth. Journal of Economic Perspectives, 9(2), 23-44.

Boubtane, E Coulibaly, D., \& Raul, C. (2012). Growth and Unemployment: Panel VAR Evidence from

OECD Countries. IZA DP No. 6966October 2012. http://ftp.iza.org/dp6966.pdf. 
Hathaway, J.C., \& Neve, R.A., (1997). Making international refugee law relevant again: a proposal for collectivized and solution-oriented protection. Harvard Human Rights Journal, 10, 115-211.

Hopstock, N. \& De Jager, N. (2011). Locals only: Understanding xenophobia in South Africa. Strategic Review for Southern Africa, 33(1), 120-139.

IFS Statistic and World Bank Development Index websites (2019). https://data.worldbank.org/.

ILO Statistics (2019). https://ilostat.ilo.org/topics/population-and-labour-force.

Ivanov, S \& Stavrinoudis, T. A (2018). Impacts of the refugee crisis on the hotel industry: Evidence from four Greek islands. Tourism Management, 67, 214-223

Ivanov, S., Gavrilina, M., Webster, C., \& Ralko, V. (2017). Impacts of political instability on the tourism industry in Ukraine. Journal of Policy Research in Tourism, Leisure and Events, 9(1), 100-127.

Ivanov, S., Idzhylova, K., \& Webster, C. (2016). Impacts of the entry of the Autonomous Republic of Crimea into the Russian Federation on its tourism industry: An exploratory study. Tourism Management, 54, 162-169.

Ivanov, S., Sypchenko, L., \& Webster, C. (2017). International sanctions and Russia's hotel industry: The impact on business and coping mechanisms of hoteliers. Tourism Planning \& Development, 14(3), 430-441.

Lastrapes, W.D., \& Lebesmuehlbacher, T., (2016). The European Refugee Crisis and House Prices: Evidence from the United Kingdom. Working paper. University of Georgia, Athens (GA).

Legrain, P. (2016). Refugees Work: A Humanitarian Investment That Yields Economic Dividends. Tent Foundation, May. www.tent.org/wp-content/uploads/2016/05/Tent-OpenRefugeesWork_VFINALsinglepages.pdf.

Lischer, S. K (2005). Dangerous Sanctuaries: Refugee Camps, Civil War, and the Dilemmas of Humanitarian Aid. Ithaca, NY: Cornell University Press.

LoPalo, M (2019). The effect of cash assistance on refugee outcomes, Journal of Public Economics, 170, 27-52.

Love, I., \& Zicchino, L. (2006). Financial Development and Dynamic Investment Behaviour: Evidence from panel VAR. The Quarterly Review of Economics and Finance, 46(2), 190-210.

Milner, J (2016). When Norms Are Not Enough: Understanding the Principle and Practice of Burden and Responsibility Sharing for Refugees. Global Leadership and Cooperation for Refugees Series Paper No. 2, December. Waterloo, ON: CIGI. www.cigionline.org/sites/default/files/documents/Refugee\%20Paper\%20no2web_3.pdf.

OECD, (2017). Finding Their Way: Labour Market Integration of Refugees in Germany. March. Paris, France: OECD. www.oecd.org/els/ mig/Finding-their-Way-Germany.pdf.

Rother, B., Pierre, G., \& Lombardo, D. (2016). The Economic Impact of Conflicts and the Refugee Crisis in the Middle East and North Africa. IMF Staff Discussion Note SDN/16/08. International Monetary Fund, Washington, DC.

Sa, F., (2015). Immigration and house prices in the UK. Econ. J. 125, 1393-1424.

Saiz, A., \& Susan, W. (2011). Immigration and the Neighbourhood. American Economic Journal: Economic Policy, 3 (2), $169-88$.

Salehyan, I., \& Kristian, S. (2006). Refugees and the Spread of Civil War. International Organization, 60(2), 335-66.

Schuck, P. (1997). Refugee burden-sharing: a modest proposal. Yale Journal of International Law, 22, 243-297. 
Tumen, S., (2016). The economic impact of Syrian refugees on host countries: quasi experimental evidence from Turkey. Am. Econ. Rev, 106, 456-460.

UNHCR (2004). Economic and Social Impacts of Massive Refugee Populations on Host Developing Countries, as Well as Other Countries." Standing Committee. UNHCR, EC/54/SC/CRP.5.

UNHCR (2017). Global Trends: Forced Displacement in 2016. Geneva, Switzerland: UNHCR. www.unhcr.org/5943e8a34.pdf.

Refugee Statistics - UNHCR (2019). www.unhcr.org > refugee-statistics.

Vuuren, A. V., Kjellander, J., \& Nilsson, V. (2019). Refugee and apartment prices: A case study to investigate the attitudes of home buyers. Regional Science and Urban Economics, Elsevier, 77(C), 20-37.

Weber, E., \& Weigand, R. (2016). Identifying macroeconomic effects of refugee migration to Germany. IAB Discussion Paper Articles on labour market issues20/2016. http://doku.iab.de/discussionpapers/2016/dp2016.pdf.

Wilkinson, R. (2004). Why is violence more common where inequality is greater? Ann N Y Acad Sci, 1036, 1-12.

Word Bank (2012). Guidelines for Assessing the Impacts and Costs of Forced Displacement. Washington DC.

Yogo, T. (2017). Are Refugees a fiscal burden for Europe? Evidence from a Panel VAR analysis. https://papers.ssrn.com/sol3/papers.cfm?abstract_id=2911764.

Zenker, S., Wallpach, S. V., Braun, E., \& Vallaster, C. (2019). How the refugee crisis impacts the decision structure of tourists: A country scenario study. Tourism Management, 71, 197- 212.

Zolberg, A., Suhrke, A., \& Aguayo, S. (1989). Escape from Violence: Conflict and Refugee Crisis in the Developing World. Oxford, UK: Oxford University Press. 